\title{
Silicosis and Urinary Analysis
}

\author{
Hilal Altınöz, ${ }^{1}$ Gülçin Kantarcı, ${ }^{2}$ Zehra Eren, ${ }^{2}$ Cengiz Çelikkalkan, ${ }^{3}$ \\ Veli Göylüsün, ${ }^{3}$ Birsen Ocaklı
}

\footnotetext{
'Department of Chest Diseases, Süreyyapaşa Thoracic Diseases and Thoracic Surgery Training Hospital, İstanbul, Turkey ${ }^{2}$ Department of Nephrology, Yeditepe University Faculty of Medicine, İstanbul, Turkey ${ }^{3}$ Department of Pulmonology, Istanbul Occupational Disease Hospital, Istanbul, Turkey

Submitted: 02.03 .2018 Accepted: 26.04 .2018

Correspondence: Dr. Hilal Altınöz, Süreyyapaşa Göğüs Hastalıkları ve Cerrahisi Eğitim ve Araştırma Hastanesi, Göğüs Hastalıkları Kliniği, İstanbul, Turkey

E-mail: hilalaltinoz@yahoo.com

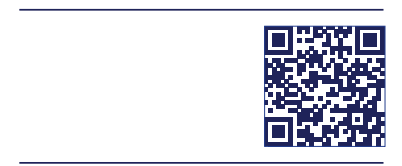

Keywords: Mortality; nephropathy; silicosis; urine.
}

\begin{abstract}
Objective: Occupational exposure to silica has been thought to be associated with renal diseases for some 40 years, but there are no data about the kidney function of silicosis patients in Turkey.
\end{abstract}

Methods: In this study we examined the kidney function and urinary test results of all of the silicosis patients diagnosed at Istanbul Occupational Disease Hospital between March I, $20 \mathrm{II}$ and May 3I, 20II, and the death rate of those patients as of May $20 \mathrm{I} 4$.

Results: Urinary pathology was seen mostly in patients working as denim sandblasters and in glass sandblasters. However, urine abnormalities did not affect the 3-year mortality.

Conclusion: A urinary analysis and renal function evaluation of patients who are exposed to silica should not be neglected. Although urinary pathology was not shown to affect the 3-year mortality in silicotic patients, in the long-run we assume that it may lead to renal nephropathies and premature death, especially in denim sandblasters and glass sandblasters.

\section{INTRODUCTION}

It has been suspected for nearly 40 years that the kidneys are affected by exposure to silica particles. There are case reports of an association between silica exposure and various forms of kidney disease.

Silica exposure has been associated with focal glomerulonephritis, proliferative glomerulonephritis, Goodpasture syndrome, crescentic glomerulonephritis, immunoglobulin A nephropathy, polyarteritis nodosa, and Wegener's granulomatosis. ${ }^{[1]}$

The mechanism by which silica damages the renal system may be either through direct (silica particles in the kidney) or indirect toxicity that can activate the immune system and can lead to glomerular damage. ${ }^{[2]}$ Currently, there are no data available about the kidney function of silicosis patients in Turkey. Hence, this study was designed to fill this gap in the understanding of renal function in patients with silica nephropathy and to determine the effect on 3-year mortality in Turkey.

\section{MATERIAL AND METHODS}

This was a retrospective cohort study. The records of all of the silicosis patients diagnosed at Istanbul Occupational Disease Hospital between March I, 20 I I and May 3 I, 20 I I were assessed. All of the patients had a chest X-ray, and high-resolution computed tomography was performed as needed. All of the cases were classified according to the International Labour Organization (ILO) classification system (revised 2000). ${ }^{[3]}$ Respiratory function tests were performed in order to measure pulmonary function.

According to the ILO classification system, the radiological propagation was as follows:

Category I: I/0, I/I, I/2 
Category 2: 2/I, 2/2, 2/3

Category 3: 3/2, 3/3, 3/+

Urine and blood samples were obtained. Hemogram results and those of routine biochemical tests, including blood urea nitrogen (BUN), creatinine, and serum calcium level, were evaluated. Urinalysis was performed to detect the presence of protein, erythrocytes ( 3 or more), leukocytes (6 or more), calcium oxalate crystals, cylinders, etc.

The primary outcome was the urinary pathology, and the secondary outcome was mortality in 3 years.

Notification of patient death was obtained from national death records.

The results were provided as mean \pm SD or median $\left(25^{\text {th }}\right.$ $75^{\text {th }}$ percentile) for numerical variables, and percentages for categorical variables. A chi-square test and the MannWhitney $U$ test were used with SPSS for Windows, Version 16.0 (SPSS, Inc., Chicago, IL, USA).

\section{RESULTS}

In the aforementioned period, 184 silicosis patients (male: $n=183$ ) were diagnosed. They were demographically and radiologically evaluated, and renal function was assessed.

The average age of the patients was $34.03 \pm 9.5$ years (minmax: 20-72 years).

As seen in Table I, the most common occupations associated with silica nephropathy were denim sandblasters (83.2\%), followed by dental technicians (5.4\%), glass sandblasters $(2.7 \%)$, stone cutters $(1.6 \%)$, and coal miners (I.6\%).

Table I. Occupation of the study patients

\begin{tabular}{lcc}
\hline Occupation & n & \% \\
\hline Denim sandblasting & 153 & 83.2 \\
Dental technician & 10 & 5.4 \\
Glass sandblasting & 5 & 2.7 \\
Stone cutter & 3 & 1.6 \\
Coal mine worker & 3 & 1.6 \\
Quartz milling worker & 2 & 1.1 \\
Sand blasting of vessel & $\mathrm{I}$ & 0.5 \\
Sand blasting of cookware & $\mathrm{I}$ & 0.5 \\
Ceramic sink production & $\mathrm{I}$ & 0.5 \\
Metal tool grinding & $\mathrm{I}$ & 0.5 \\
Welding electrode packing & $\mathrm{I}$ & 0.5 \\
Iron worker & $\mathrm{I}$ & 0.5 \\
Denim grinding & $\mathrm{I}$ & 0.5 \\
Total & 184 & 100 \\
\hline
\end{tabular}

The average length of silica exposure was $5.68 \pm 6.13$ years (min-max: $0.25-38$ years). Smoking history revealed that $37.7 \%$ of the patients had never smoked, $23.4 \%$ had quit smoking, and $38.4 \%$ were still smoking. The average number of pack-years was $7.49 \pm 8.2$.

Results of pulmonary function tests performed revealed $31.5 \%$ restrictive and $22.1 \%$ obstructive pathologies.

Radiological studies using the ILO classification system showed that $49.2 \%$ of the patients were in category 3 , $39.9 \%$ in category $2,10.9 \%$ in category I, and $67.8 \%$ of the patients showed no large area of opacity.

No concurrent diseases were seen in 156 (84.7\%) of the patients. Nine patients presented with chronic obstructive pulmonary disease and 4 presented with asthma as well. None of the patients had a previously known renal disorder.

The average hemoglobin level of the patients studied was $14.86 \pm 1.3 \mathrm{~g} / \mathrm{dL}$ (min-max: $11.4-19 \mathrm{~g} / \mathrm{dL}$ ), while the average creatinine level was $0.87 \pm 0.1 \mathrm{mg} / \mathrm{dL}$ (min-max: $0.57-1.12$ $\mathrm{mg} / \mathrm{dL}$ ) and the average BUN was $31.32 \pm 7.2 \mathrm{mg} / \mathrm{dL}$ (minmax:16-45 mg/dL). The mean blood calcium level was $9.43 \pm 0.7 \mathrm{mg} / \mathrm{dL}$ (min-max: $8-15 \mathrm{mg} / \mathrm{dL}$ ).

The urinalysis results of 119 patients indicated that 36 $(30 \%)$ were abnormal. Erythrocytes were observed in the urine in $4.2 \%$ of the cases and $5 \%$ revealed leukocytes. In all, $13.4 \%$ of the cases were positive for the presence of calcium oxalate crystals. The urine analysis of I patient sample $(0.8 \%)$ revealed urate crystals and I other $(0.8 \%)$ revealed cylinders. None of the urinalysis results revealed protein.

The most frequently observed occupations of patients with calcium oxalate in the urine were denim sandblasting and glass sandblasting (I2.8\% and $66 \%$, respectively). None of the dental technicians had calcium oxalate in the urine test. There were no significant differences between occupation groups in the urine analysis test results $(p=0.399)$.

No correlation was determined between radiological profusion and the urine analysis results.

As a secondary result, the 3-year mortality as of May 2014 according to the national death records was researched, and it was determined that $6(3 \%)$ patients were deceased. Two of those were coal miners and 4 were sandblasters. There was no relationship found between urine abnormality and death rate, as only I of the patients with an abnormal urine result was determined to have died. The mean age of the deceased patients was 43.28 years. Half had stage 3 profusion or greater. Three had a tuberculosis history.

\section{DISCUSSION}

Silicosis causes urine abnormality; however, the mortality of silicosis patients does not increase according to this abnormality. In this study, 36 patients (30\%) presented with 
pathology in the urine analysis and 6 (3\%) were dead after 3 years, only I of whom had an abnormal urinalysis result.

There are several case studies and mortality studies related to silica exposure and renal functional disorders. Saldanha et al. ${ }^{[4]}$ were the first to write about a case with albuminuria and high blood pressure along with industrial silicone exposure, describing silicone in renal tissue and modification of the proximal tubules. An epidemiological study was performed by Calvert et al. ${ }^{[5]}$ investigating gold miners' silicosis and end-stage renal diseases. Steenland et al. ${ }^{[6]}$ reported that occupational silica exposure increased the risk of end-stage renal disorder 14\%. MacDonald et al. ${ }^{[7]}$ conducted a mortality study and showed that quartz exposure in North American industrial sandblasting workers increased mortality due to lung cancer, but not due to chronic renal disorders or renal cancer. Olsen et al. ${ }^{[8]}$ also researched the mortality of silica-exposed workers at 4 plants and demonstrated that 16 workers $(2 \%)$ had died as a result of nonmalignant renal disease among 772 total deaths. In the same study, 50 deaths (6\%) were attributed to nonmalignant respiratory system disease, and a total of 77 (1\%) lung cancer deaths. In our study, we found that an abnormality in the urine analysis did not correlate with increased death over a 3-year period.

Rosenman et al. ${ }^{[9]}$ studied 583 cases of silicosis in a cohort study. They reported that 10\% of the cases were suspected of having a chronic renal disorder according to their history and the laboratory work indicated that 33\% of the patients had a serum creatinine level of $>1.5 \mathrm{mg} /$ $\mathrm{dL}$. There was no relationship between the duration of silica exposure and the prevalence of kidney disease or elevated creatinine. Vupputuri et al. ${ }^{[10]}$ also found a positive relationship between occupational silica exposure and chronic kidney disease. A dose-response trend of increasing chronic kidney disease with increasing silica exposure was also observed in the same study, especially in nonwhites. In our study, we found no association between radiological profusion or the existence of opacity and the results of urinalysis.

There are no reports in the medical literature indicating which types of job increase kidney pathology in silicosis patients. In our study, we observed that calcium oxalate was frequently seen in denim sandblasting workers and glass sandblasting workers, while there were no instances among dental technicians. We suggest that new studies concerning the characteristics of the silica particles be performed to ascertain the effects on the kidneys. Furthermore, we suggest that more significance must be given to the kidney function of the denim and glass sandblasters.

The main limitation of this study is that we were not able to get the urinary sample results of all of the patients. As this is a single-center study, multicenter cohort studies should be conducted.

\section{CONCLUSION}

A urinary evaluation of patients who are exposed to silica should not be neglected. The exposure to silica is related to urinary pathologies. Though calcium oxalate was seen in the urine analysis of $66 \%$ of the glass sandblasting workers, the results of this study must be compared with others, since the power of this study is low. Although the 3-year mortality was not affected by urinary pathology in these silicotic patients, we believe that in the long-run, nephropathy may lead to premature death, particularly in denim sandblasters and glass sandblasters.

\section{Acknowledgment}

This study was orally presented at the $33^{\text {rd }}$ National Congress of the Turkish Respiratory Society on October 17, 2011 in Cesme, Turkey.

Ethics Committee Approval

Approved by Yeditepe University Faculty of Medicine Clinical Research Assessment Committee (date: June 14, 20II; no.: I 10).

Informed Consent

Retrospective study.

Peer-review

Internally peer-reviewed.

Authorship Contributions

Concept: H.A.; Design: H.A., G.K., Z.E.; Data collection \&/or processing: H.A., C.Ç., V.G.; Analysis and/or interpretation: H.A., G.K.; Literature search: H.A., G.K., Z.E.; Writing: H.A., B.O.; Critical review: H.A.

Conflict of Interest

None declared.

\section{REFERENCES}

1. Park CG, Conrad K, Cooper GS. Occupational exposure to crystalline silica and autoimmune disease. Environ Health Perspect 1999;107:793-802. [CrossRef]

2. Kallenberg CGM. Renal disease-another effect of silica exposure? Nephrol Dial Transplant 1995;10:1117-9.

3. International Labour Office. Guidelines for the use of the ILO International Classification of Radiographs of Pneumoconioses, Revised edition 2000. Occupation- al Safety and Health Series No. 22 (Rev. 2000). Geneva; 2002. Available at: http://www.ilo.org/wcmsp5/ groups/public/-.--ed_protect/---protrav/---safework/documents/ publication/wcms_108568.pdf, Accessed Apr 27, 2018.

4. Saldanha LF, Rosen VJ, Gonick HC. Silicon nephropathy. Am J Med 1975;59:95-103. [CrossRef]

5. Calvert GM, Steenland K, Palu S. End-stage renal disease among silica-exposed gold miners. A new method for assessing incidence among epidemiologic cohorts. JAMA 1997;277:1219-23. [CrossRef]

6. Steenland K, Sanderson W, Calvert GM. Kidney disease and arthri- 
tis in a cohort study of workers exposed to silica. Epidemiology 2001;12:405-12. [CrossRef]

7. McDonald JC, McDonald AD, Hughes JM, Rando RJ, Weill H. Mortality from lung and kidney disease in a cohort of North American industrial sand workers: an update. Ann Occup Hyg 2005;49:367-73.

8. Olsen GW, Andres KL, Johnson RA, Buehrer BD, Holen BM, Morey SZ, et al. Cohort mortality study of roofing granule mine and mill workers. Part II. Epidemiologic analysis, 1945-2004. J Occup Environ Hyg 2012;9:257-68. [CrossRef]

9. Rosenman KD, Moore-Fuller M, Reilly MJ. Kidney disease and silicosis. Nephron 2000;85:14-9. [CrossRef]

10. Vupputuri S, Parks CG, Nylander-French LA, Owen-Smith A, Hogan SL, Sandler DP. Occupational silica exposure and chronic kidney disease. Ren Fail 2012;34:40-6. [CrossRef]

\section{Silikozis ve Idrar Analizi}

Amaç: Mesleki silika maruziyetinin böbrek hastalıklarıyla ilişkisi yaklaşık 40 yıldır biliniyor, fakat halen Türkiye'deki silikoz hastalarının böbrek fonksiyonları hakkında bir verimiz yok.

Gereç ve Yöntem: Bu çalışmada İstanbul Meslek Hastalıkları Hastanesinde 01.03.20I I ve 31.05 .201 I tarihleri arasında tanısı konmuş tüm silikoz hastalarının böbrek fonksiyonları ve idrar tahlillerini ve Mayıs 2014'te ölüm oranlarını inceledik.

Bulgular: İdrar patolojisi kot kumlama ve cam kumlama işçisi olarak çalışanlarda daha sık görüldü. Bununla beraber idrar anormallikleri 3 yıllık mortaliteyi etkilemiyordu.

Sonuç: Silikaya maruz kalan hastalarda idrar analizi ve böbrek fonksiyon analizi ihmal edilmemelidir. Silikotik hastalarda idrar testi bozukluğunun, üç yıllık mortaliteyi etkilemediğinin gösterilmiş olmasına rağmen uzun dönemde, özellikle kot kumlama ve cam kumlama işçilerinde böbrek fonksiyon bozukluğu ve erken ölümlere yol açabileceği kanısındayız.

Anahtar Sözcükler: İdrar; mortalite; nefropati; silikoz. 